\title{
Greenalite Nanoparticles in Alkaline Vent Plumes as Templates for the Origin of Life
}

\author{
B. Rasmussen, ${ }^{1}$ J.R. Muhling, ${ }^{1}$ and W.W. Fischer ${ }^{2}$
}

\begin{abstract}
Mineral templates are thought to have played keys roles in the emergence of life. Drawing on recent findings from 3.45-2.45 billion-year-old iron-rich hydrothermal sedimentary rocks, we hypothesize that greenalite $\left(\mathrm{Fe}_{3} \mathrm{Si}_{2} \mathrm{O}_{5}(\mathrm{OH})_{4}\right)$ was a readily available mineral in hydrothermal environments, where it may have acted as a template and catalyst in polymerization, vesicle formation and encapsulation, and protocell replication. We argue that venting of dissolved $\mathrm{Fe}^{2+}$ and $\mathrm{SiO}_{2}(a q)$ into the anoxic Hadean ocean favored the precipitation of nanometer-sized particles of greenalite in hydrothermal plumes, producing a continuous flow of free-floating clay templates that traversed the ocean. The mixing of acidic, metal-bearing hydrothermal plumes from volcanic ridge systems with more alkaline, organic-bearing plumes generated by serpentinization of ultramafic rocks brought together essential building blocks for life in solutions conducive to greenalite precipitation. We suggest that the extreme disorder in the greenalite crystal lattice, producing structural modulations resembling parallel corrugations $(\sim 22 \mathrm{~A}$ wide) on particle edges, promoted the assembly and alignment of linear RNA-type molecules ( $\sim 20 \AA$ diameter). In alkaline solutions, greenalite nanoparticles could have accelerated the growth of membrane vesicles, while their encapsulation allowed RNA-type molecules to continue to form on the mineral templates, potentially enhancing the growth and division of primitive cell membranes. Once self-replicating RNA evolved, the mineral template became redundant, and protocells were free to replicate and roam the ocean realm. Key Words: Origin of lifeAlkaline vents-Greenalite-Clay templates-RNA-Hydrothermal sediments. Astrobiology 21, 246-259.
\end{abstract}

\section{Introduction}

T HE EMERGENCE OF LIFE required processes that produced the chemical compounds essential for biosynthesis as well as conditions that allowed the assembly of genetic polymers in protocells that could grow, divide, and evolve (Szostak, 2017). Hydrothermal environments, including terrestrial hot springs and seafloor vents, are regarded as ideal environments for life's origin because they create extreme physical and chemical gradients and are a source of relevant molecules for the synthesis of biochemical building blocks (e.g., lipids, amino acids, nucleotides) (Corliss et al., 1981; Baross and Hoffman, 1985; Huber and Wächtershäuser, 1997, 1998, 2006; Russell and Hall, 1997; Cody et al., 2000; Kelley et al., 2001; Russell et al., 2005; Martin et al., 2008, 2014; Mielke et al., 2010; Mulkidjanian et al., 2012; Yamaguchi et al., 2014; Deamer and Georgiou,
2015; Roldan et al., 2015; Kitadai et al., 2018; Li et al., 2018; Ooka et al., 2018; Westall et al., 2018; Jordan et al., 2019; White et al., 2020).

Because prebiotic organic compounds were probably extremely dilute in Hadean water masses, several mechanisms have been proposed to increase their concentration, including wetting-drying cycles in shallow ponds or lakes (Damer and Deamer, 2015), eutectic freezing (Kanavarioti et al., 2001), and adsorption onto the surfaces of gels and/or minerals via weak noncovalent bonds (Bernal, 1949; Cairns-Smith, 1965, 1982; Ferris et al., 1996; Russell and Hall, 1997; Huber and Wächtershäuser, 1998; Parsons et al., 1998; Greenwell and Coveney, 2006; Westall et al., 2018).

A vast array of potential minerals has been invoked as playing one or more roles in the emergence of life, including members of major mineral groups such as oxides/hydroxides, sulfides, carbonates, borates, and silicates (Arrhenius, 2003;

\footnotetext{
${ }^{1}$ School of Earth Sciences, The University of Western Australia, Perth, Australia.

${ }^{2}$ Division of Geological and Planetary Sciences, California Institute of Technology, Pasadena, California, USA.

(C) B. Rasmussen et al., 2020; Published by Mary Ann Liebert, Inc. This Open Access article is distributed under the terms of the Creative Commons Attribution Noncommercial License (http://creativecommons.org/licenses/by-nc/4.0/) which permits any noncommercial use, distribution, and reproduction in any medium, provided the original author(s) and the source are credited.
} 
Hazen and Sverjensky, 2010; Russell, 2018). Clay minerals (as defined by Bailey, 1980) are considered particularly suitable substrates for the assembly of genetic polymers (Bernal, 1949; Cairns-Smith, 1965, 1982; Rao et al., 1980; Ferris and Ertem, 1992; Ferris, 2002, 2005; Jelavic et al., 2017), because of their high reactivity, large surface area, regular layered structure, and likely abundance in aqueous environments.

Experimental studies have shown that activated clay mineral surfaces (e.g., montmorillonite) promote the oligomerization of activated monomers (Ferris, 2002, 2005; Ferris et al., 1989a, 1989b, 1996; Franchi et al., 1999; 2003; Biondi et al., 2007; Joshi et al., 2009; Feuillie et al., 2013; Pedreira-Segade et al., 2016) and the assembly of primitive vesicles (Hanczyc et al., 2003). According to the "RNA world" hypothesis, the formation of RNA was a key step in the origin of life, because it could perform vital functions such as catalysis and transfer of genetic information, allowing the inheritance of useful functions essential for Darwinian evolutionary processes to occur (Gilbert, 1986; Joyce, 2002; Szostak, 2017).

Most clay minerals in seafloor hydrothermal vent systems form via in situ replacement of olivine, pyroxene, and plagioclase during seawater infiltration of mafic-ultramafic rocks (Meunier et al., 2010; Menez et al., 2018; Tutolo et al., 2019; Templeton and Ellison, 2020). Recent work by Menez et al. (2018) suggests that Fe-saponite in serpentinites from the Lost City field, Mid Atlantic Ridge, may have played a role in generating organic compounds including amino acids. An important question, which remains open, is how amino acids and other basic building blocks (e.g., lipids, nucleotides) combined to form the first protocells capable of replication.

In this paper, we hypothesize that the Fe(II)-silicate mineral greenalite, which probably formed continuously in hydrothermal vent plumes soon after the first oceans formed, is a geologically plausible template for the assembly of genetic biomolecules and formation of vesicles. Greenalite nanoparticles have been observed in hydrothermally derived chemical sediments (i.e., banded iron formation [BIF] and ferruginous chert) deposited in early oceans between 3.45 and 2.45 billion years ago (Rasmussen et al., 2014, 2015, 2017, 2019a, 2019b; Johnson et al., 2018; Muhling and Rasmussen, 2020). Their depositional microfabric suggests that the nanoparticles settled from hydrothermal plumes as dense suspensions of iron-rich muds (Rasmussen et al., 2019a).

The chemical conditions conducive to greenalite precipitation, which include anoxic water enriched in dissolved $\mathrm{Fe}^{2+}$ and $\mathrm{SiO}_{2}$ (Tosca et al., 2016, 2019), are likely to have existed throughout the Hadean ocean. The increase in nucleation with rising alkalinity (Tosca et al., 2016) suggests that greenalite precipitation would have been enhanced in the mixing zones between hydrothermal plumes of acidic, $\mathrm{Fe}^{2+}$-bearing "black smokers" and alkaline organic-bearing plumes developed above serpentinizing ultramafic rocks. We hypothesize that these mixing zones not only brought together the molecular constituents and building blocks for abiogenesis but also triggered the rapid precipitation of greenalite nanoparticles, which catalyzed the assembly of genetic material and growth of primitive vesicles. Although our hypothesis is based on observations from submarine hydrothermal sediments, it is possible that greenalite nanoparticles could have played a similar role in terrestrial hot springs and pools on early Earth and potentially on Mars. To test our hypothesis, we propose a series of experiments to investigate the role of greenalite in the concentration of nucleotides and their assembly of linear chains, and the formation of primitive membranes.

\section{Greenalite Nanoparticles in Ancient Hydrothermal Sediments}

Hadean oceanic crust is not preserved in the rock record, and hence it is difficult to know what marine phases were deposited around the earliest seafloor vents. Some information can be gleaned from BIFs, which are chemical sediments derived largely from seafloor hydrothermal vents (Derry and Jacobsen, 1990; Bekker et al., 2014). These marine sediments comprise iron-rich ( $>15 \mathrm{wt} \% \mathrm{Fe})$ and silica-rich $(>40 \mathrm{wt} \% \mathrm{Si}$ ) bands and occur in some of Earth's oldest sedimentary rocks (between 3.7 and $2.4 \mathrm{Ga}$ ) (Klein, 2005; Beukes and Gutzmer, 2008; Fischer and Knoll, 2009; Bekker et al., 2014). Their rare earth element and $\mathrm{Nd}$-isotope composition indicates derivation from high-temperature hydrothermal alteration of mafic crust (Jacobsen and Pimentel-Klose, 1988). The deposition of BIFs on continental margins indicates that Fe was probably transported long distances $(>1000 \mathrm{~km})$ from the hydrothermal source (Bekker et al., 2014). The silica-rich bands comprise mainly chert and are widely interpreted to be early diagenetic cements, indicating that the oceans were at times close to or above saturation with respect to amorphous silica or cristobalite (Siever, 1992).

The composition of the initial Fe-rich precipitates of BIFs is uncertain. Potential candidates include ferrihydrite, "green rust," siderite, magnetite, and greenalite (Klein, 2005; Beukes and Gutzmer, 2008; Fischer and Knoll, 2009; Bekker et al., 2014; Rasmussen et al., 2015; Halevy et al., 2017). The current consensus favors ferric oxide/hydroxide precipitates (Konhauser et al., 2017) whose formation in largely anoxic oceans has been explained by invoking biologically mediated oxidation of vent-derived $\mathrm{Fe}^{2+}$ that upwelled onto continental margins.

However, recent high-resolution microscopic studies of 3.45-2.45 Ga BIFs and cherts from Archean cratons in Australia and South Africa show that dissolved iron was deposited from the ocean as a ferrous silicate mineral-greenalite (ideal formula $\left[\mathrm{Fe}_{3} \mathrm{Si}_{2} \mathrm{O}_{5}(\mathrm{OH})_{4}\right]$ ) (Figs. 1 and 2) (Rasmussen et al., 2015, 2017, 2019a, 2019b; Johnson et al., 2018; Muhling and Rasmussen, 2020). Greenalite is an $\mathrm{Fe}^{2+}$-rich, $\mathrm{Al}^{3+}$-poor trioctahedral phyllosilicate with a 1:1 structure (7.0-7.2 $\AA$ ) similar to serpentine group minerals (Guggenheim and Eggleton, 1998). A misfit between the octahedral and tetrahedral sheets produces the modulated crystal structure ( $\sim 22 \AA$ wide) (Fig. 3), which is characteristic of greenalite (Tosca et al., 2016).

In bands of ferruginous chert and BIF, greenalite occurs as minute particles (typically between 50 and $500 \mathrm{~nm}$ long) that are randomly oriented and uniformly distributed in silica cement (Fig. 2). The greenalite particles comprise $5-15 \%$ of the bands, whereas chert makes up the remaining $85-95 \%$ (Fig. 2C, 2D). The distribution and orientation of the greenalite particles closely resemble the texture of freshly deposited muds (Bennett et al., 1981, 1991; Kase et al., 2016) and frozen clay slurries (Deirieh et al., 2018), which commonly comprise 5-20\% mud and 80-95\% water. The microfabric of the greenalite-chert bands indicates that some of the ferrous silicate particles settled from suspension as colloidal flocs 


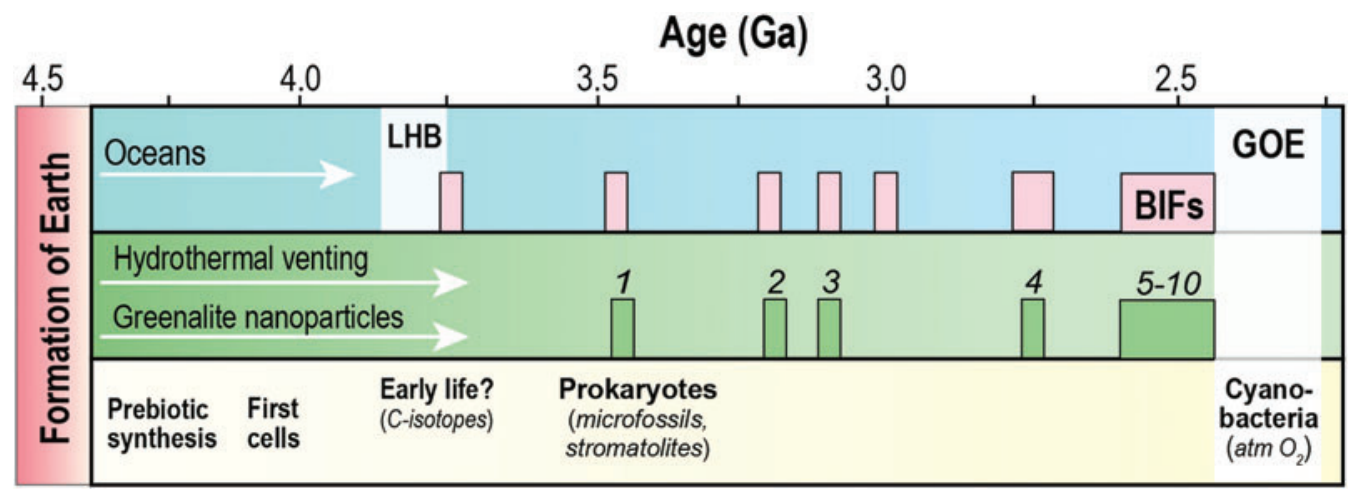

FIG. 1. Major geological and biological events during the first 2 billion years of Earth's history. Greenalite nanoparticles preserved in marine sedimentary cherts from 3.45- to 2.45-billion-year-old banded iron formations $(\mathrm{BIFs})$. LHB $=\mathrm{Late}$ heavy bombardment; GOE= Great Oxidation Event. (1) 3.45 Ga Marble Bar Chert, Western Australia; (2) 3.20 Ga Gorge Creek Group; (3) 3.10 Ga Nimingarra Iron Formation; (4) 2.75 Ga Weld Range iron formation; (5) 2.63 Ga Jeerinah Formation; (6) 2.60 Ga Marra Mamba Iron Formation; (7) 2.56 Ga Wittenoom Formation; (8) 2.55 Ga Mt Sylvia Formation; (9) $2.50 \mathrm{Ga}$ Mt McRae Shale; (10) 2.50-2.45 Ga Brockman Iron Formation. Color images are available online.

(Rasmussen et al., 2019a). The abundance and distribution of the greenalite nanoparticles in BIFs (Rasmussen et al., 2015, 2017; Johnson et al., 2018; Muhling and Rasmussen, 2020) indicates that the ferrous silicate was the main iron-rich precipitate in the early Precambrian ocean and may have been abundant around submarine hydrothermal vents.

\section{Experimental Growth of Greenalite Nanoparticles}

High-resolution microscopic observations from the ancient rock record are consistent with low-temperature $\left(25^{\circ} \mathrm{C}\right)$ experimental studies of solutions simulating the composition of Archean seawater (Tosca et al., 2016, 2019; Jiang and
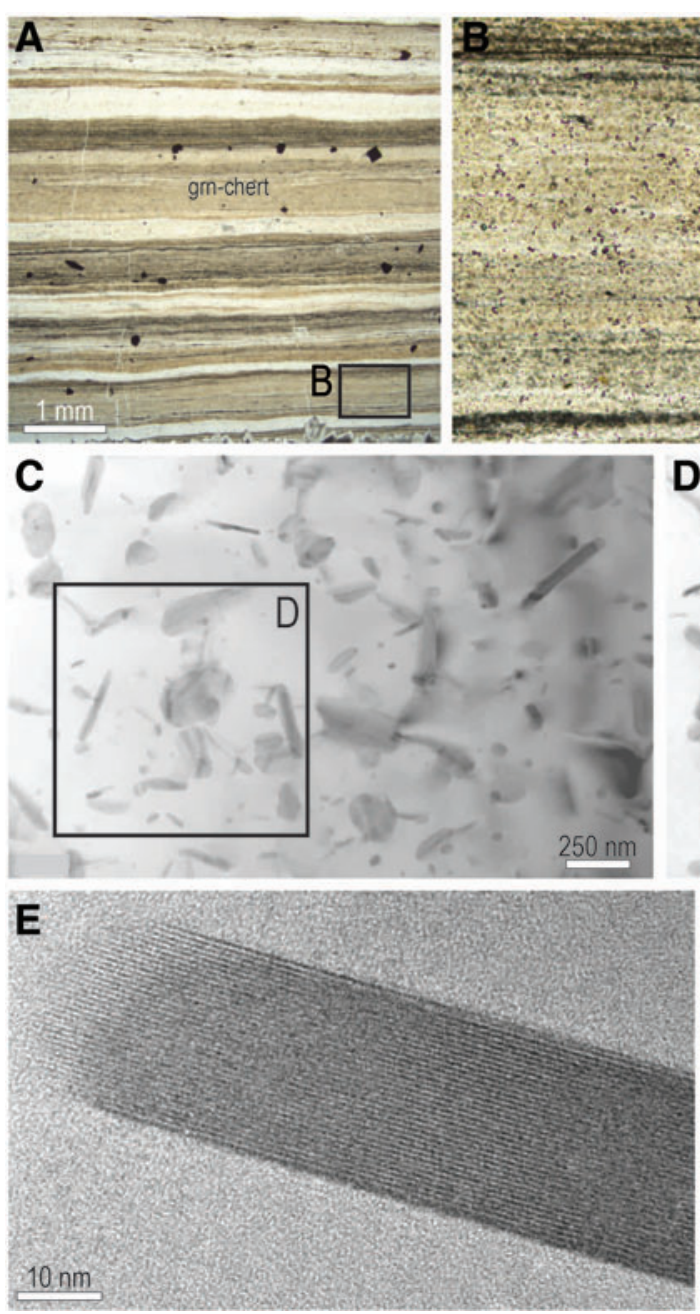
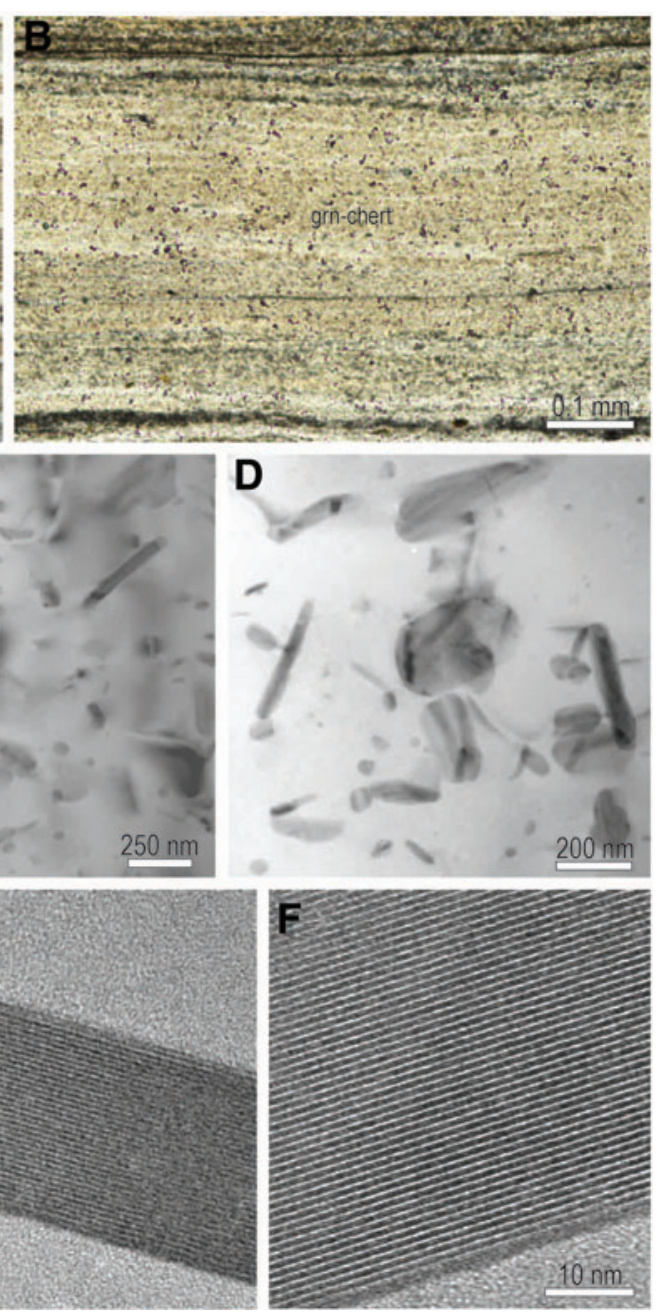

FIG. 2. (A) Polished thin section of finely laminated, greenalite-rich chert. (B) Plane polarized light image of laminated, greenalite-rich chert. (C) Transmission electron microscope (TEM) bright-field image showing randomly oriented greenalite nanoparticles "floating" in chert cement. (D) TEM bright-field image of greenalite nanoparticles (inset 2C). (E, F) High-resolution (lattice fringe) TEM images of greenalite nanoparticles showing the spacing and direction of the (001) planes. Color images are available online. 

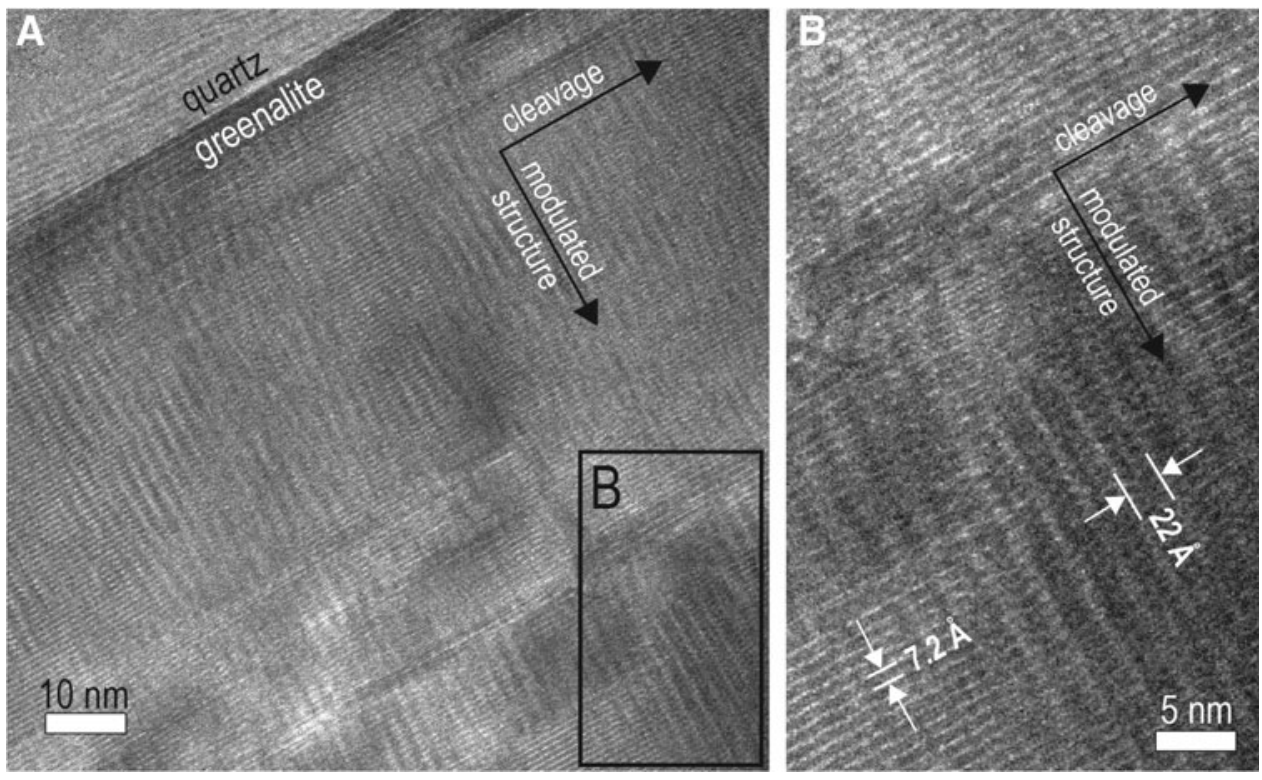

FIG. 3. (A, B) High-resolution (lattice fringe) TEM images of a greenalite particle showing the spacing (7.0-7.2 $\AA$ ) and direction of the (001) planes and the spacing $(\sim 22 \AA)$ and direction of the characteristic modulated structure.

Tosca, 2019). Using anoxic seawater-derived solutions, Tosca et al. (2016) found that $\mathrm{Fe}^{2+}$ and $\mathrm{SiO}_{2}(a q)$ readily nucleate and form a hydrous disordered Fe(II)-silicate gel. Dehydration and structural rearrangement of the gel produced nanometer-sized particles of crystalline greenalite. The solubilities of dissolved ferrous iron and silica drop sharply with increasing $\mathrm{pH}$, leading to rapid nucleation and precipitation of $\mathrm{Fe}(\mathrm{II})$-silicates (e.g., greenalite) in alkaline solutions ( $\mathrm{pH}>7$ ) (Tosca et al., 2016; Francisco et al., 2020).

\section{Submarine Hydrothermal Vent Plumes on Early Earth}

During the Hadean and early Archean, Earth's interior was likely hotter, resulting in vigorous mantle convection coupled with greater magma supply and faster seafloor spreading rates (Bickle, 1978; Isley, 1995; Isley and Abbott, 1999; Lowell and Keller, 2003; Arndt and Nisbet, 2012). The oceanic crust is thought to have been much thicker with elevated mid-ocean ridges and oceanic plateaus and a more voluminous ocean that submerged all but the highest mountain peaks (Arndt and Nisbet, 2012). A hotter oceanic crust and higher hydrothermal heat loss (up to 10 times greater than present; Lowell and Keller, 2003) suggest that the intensity of seafloor hydrothermal venting was much greater on early Earth. Given the smaller area of emergent land, the composition of the ocean was controlled more by seawater circulation through the oceanic crust than continental weathering. The early ocean is thought to have been devoid of dissolved oxygen and sulfate, and enriched in dissolved $\mathrm{Fe}^{2+}, \mathrm{SiO}_{2}(a q)$, and $\mathrm{CO}_{2}$ (Canfield, 2005; Arndt and Nisbet, 2012; Tosca et al., 2019). The pH of the early ocean was largely buffered by seawater circulation through basalt-dominated crust and may have been near neutral, although estimates vary between acidic to slightly alkaline (Sleep, 2010; Halevy and Bachan, 2017).

The infiltration and circulation of anoxic seawater through basaltic and komatiitic volcanic piles on the Hadean seafloor would have produced a range of vigorous hydrothermal vent systems emitting fluids with varied and complex chemistries. Hydrothermal activity was probably dominated by magmadriven alteration of basalt-hosted crust close to ridge axes, which in modern systems emit high-temperature $\left(350-400^{\circ} \mathrm{C}\right)$, acidic, metal-rich fluids (German and Von Damm, 2003). The hydrothermal fluids, which were likely enriched in leached molecules, including $\mathrm{Fe}^{2+}, \mathrm{Mg}^{2+}, \mathrm{Mn}^{2+}, \mathrm{H}_{2} \mathrm{~S}, \mathrm{CO}_{2}$, $\mathrm{H}_{2}, \mathrm{PO}_{4}{ }^{3-}$, and $\mathrm{CH}_{4}$, and transition metals (e.g., $\mathrm{Zn}^{2+}$, $\mathrm{Co}^{2+}, \mathrm{Cu}^{2+}$ ) (German and Von Damm, 2003), may have formed extensive plumes that spread throughout the ocean, including shallow and intermediate levels.

Lower-temperature hydrothermal vents would also have developed above mafic-ultramafic lavas that were undergoing active serpentinization. In a modern setting, serpentinization reactions at the Lost City hydrothermal vent field, Mid Atlantic Ridge, are apparently caused by downward infiltrating seawater, which produces low- to moderate-temperature (40$91^{\circ} \mathrm{C}$ ), metal-poor, alkaline ( $\mathrm{pH}$ 9-11) fluids that contain $\mathrm{H}_{2}$, $\mathrm{CH}_{4}$, and short-chain alkanes and formate (Kelley et al., 2001, 2005; Charlou et al., 2002; Proskurowski et al., 2008; Konn et al., 2015). Although these vents emit less volume of fluid and produce much smaller plumes than higher-temperature vents (e.g., black smokers), alkaline vent fields are much longer lived (>100,000 years; Ludwig et al., 2005; Schrenk et al., 2013) and were probably widespread on early Earth due to the likely abundance of ultramafic lavas (i.e., komatiites) on the ocean floor (Arndt and Nisbet, 2012).

Shortly after their discovery (Corliss et al., 1979), it was proposed that high-temperature $\left(>350^{\circ} \mathrm{C}\right)$ hydrothermal vent systems were plausible sites for the origins of life (Corliss et al., 1981; Baross and Hoffman, 1985). However, it was argued that the extremely high temperature of vent fluids would decompose rather than synthesize organic compounds unless exposure times were short (Miller and Bada, 1988). With the discovery of low-temperature $\left(<91^{\circ} \mathrm{C}\right)$ alkaline vents (Kelley et al., 2001), these cooler vents were embraced as more favorable environments because of their greater suitability for organic synthesis (Russell, 2003, 2007; Martin 
et al., 2008, 2014; Lane et al., 2010; Sojo et al., 2016; Jordan et al., 2019). However, alkaline vents do not emit abundant $\mathrm{Fe}^{2+}, \mathrm{H}^{+}, \mathrm{CO}_{2}$, bioessential metals (e.g., $\mathrm{Zn}^{2+}, \mathrm{Co}^{2+}, \mathrm{Ni}^{2+}$, $\left.\mathrm{Cu}^{2+}, \mathrm{Mo}^{2+}\right)$ or phosphate. If life arose in alkaline vent systems, then many of the molecular species from hightemperature, low-pH hydrothermal vents must have been transported to smaller alkaline plumes.

\section{Role of Greenalite Nanoparticles In Prebiotic Synthesis-A Hypothetical Scenario}

\subsection{Greenalite templates}

Greenalite is a viable template in the origin of life because of its abundance in Earth's oldest well-preserved hydrothermal sediments. Its likely growth in hydrothermal vent plumes based on experimental data and modelling (Tosca et al., 2016, 2019; Jiang and Tosca, 2019) suggests that it may have formed continuously in vent plumes as early as $\sim 4.4$ billion years ago. We envisage that in the plumes of high-temperature vent systems, some of the dissolved $\mathrm{Fe}^{2+}$ and $\mathrm{SiO}_{2}$ rapidly nucleated and precipitated as nanometersized greenalite particles. At the higher temperatures of the proximal vent plume, it is likely that the amorphous greenalite was rapidly transformed into crystalline greenalite. The growth of greenalite nanoparticles in the more acidic vent fluids would have led to the partial protonation of its surface and development of a net positive surface charge.

The plumes from high-temperature vents, which carried greenalite nanoparticles, spread and mixed with the smaller, perhaps nearby, plumes of alkaline fluids emitted from vents above serpentinizing ultramafic rocks (Fig. 4). In these mixing zones, the products of magma-driven seawater circulation through mafic/ultramafic crust were brought together with metal-poor, organic-bearing compounds (e.g., amino acids; Menez et al., 2018) at low temperatures (probably $<91{ }^{\circ} \mathrm{C}$ ) favorable for organic synthesis. The venting of hydrothermal alkaline fluids into cooler water established convection cells and turbulent mixing zones between acidic and alkaline plume water and seawater, juxtaposing fluids with extreme differences in chemistry.

The rise in $\mathrm{pH}$ of the more acidic hydrothermal plumes during mixing would have lowered the solubility of dissolved $\mathrm{Fe}^{2+}$ and $\mathrm{SiO}_{2}$, triggering the rapid nucleation and precipitation of vast numbers of nanometer-sized particles of amorphous ferrous silicate, which would have quickly crystallized to greenalite in the hydrothermal fluids. Assuming a hydrothermal $\mathrm{Fe}^{2+}$ flux similar to today (between 2.3 and $19 \times 10^{10} \mathrm{~mol} / \mathrm{year}$; Elderfield and Schultz, 1996), which is likely to be very conservative for the Hadean ocean, seafloor vents may have supplied enough $\mathrm{Fe}^{2+}$ to

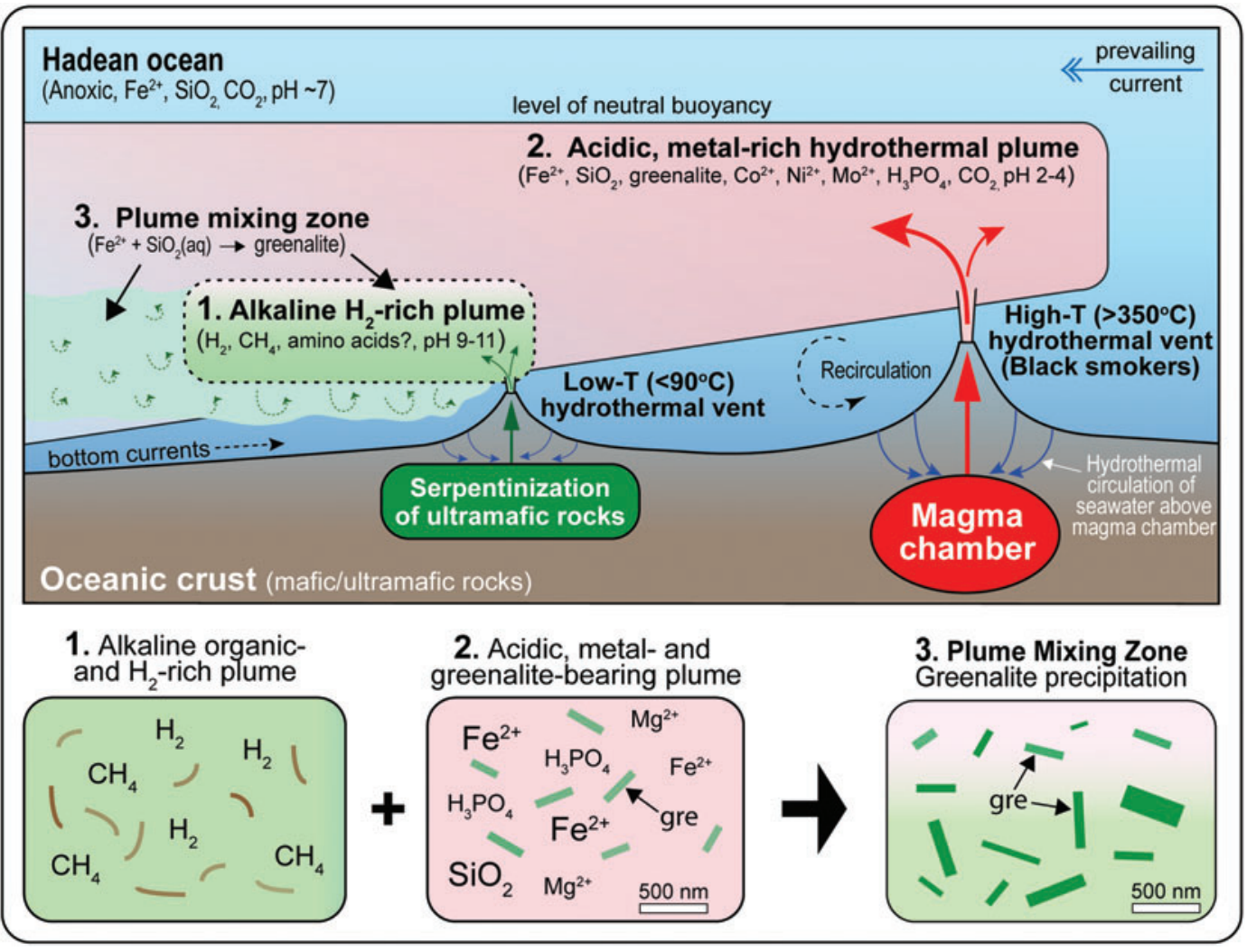

FIG. 4. Diagram showing mixing of acidic and alkaline hydrothermal plumes in the Hadean ocean. (1) The emission of alkaline, carbon- and hydrogen-rich vent fluids into water column above serpentinizing ultramafic rocks (e.g., komatiitic lavas). (2) Emission of black smoker vent plumes, enriched in metals, greenalite, and nutrients relative to seawater. (3) Mixing of acidic vent plumes with local alkaline vent plumes, bringing together the chemicals leached from mafic and ultramafic rocks. The rise in alkalinity of metal-rich plumes triggered the rapid nucleation and precipitation of greenalite nanoparticles, which catalyzed the assembly of primitive vesicles and synthesis of RNA-based genetic polymers. Color images are available online. 
produce $>10^{27}$ greenalite nanoparticles/year (assuming particle sizes of $500 \mathrm{~nm}$ by $500 \mathrm{~nm}$ by $10 \mathrm{~nm}$ ).

The greenalite nanoparticles, which varied in length from 50 to $500 \mathrm{~nm}$ ( $c f$. Rasmussen et al., 2015, 2017; Tosca et al., 2016; Muhling and Rasmussen, 2020), may have provided catalytically active templates with an enormous surface area. For 1:1 layered silicates such as greenalite, most of the surface charge is related to the broken-end hydroxyl and is dependent on the $\mathrm{pH}$ of the solution (Tombácz and Szekeres, 2006; Feuillie et al., 2013). Hence, the surface charge of greenalite nanoparticles would have undergone significant changes as they migrated between more acidic vent plumes, seawater, and alkaline vent plumes.

There is currently little data on the adsorptive or catalytic properties of greenalite; however, experiments have shown that other layered silicates such as montmorillonite attract and concentrate low-molecular-weight organic compounds and promote their assembly into larger oligomers of RNA (cf. Ferris et al., 1996; Franchi et al., 1999; Hanczyc et al., 2003; Aldersley et al., 2011; Feuillie et al., 2013; Yang et al., 2013; Pedreira-Segade et al., 2016; Jelavic et al., 2017). By virtue of its ubiquity in Archean hydrothermal sediments, greenalite may have played a key role in concentrating organic monomers on particle surfaces and catalyzing the growth of RNA-type molecules.

\subsection{Greenalite imprint on life?}

If a mineral template played a key role in the synthesis of hereditary polymers, it may have left an imprint on life. Schrödinger (1944) suggested that the template responsible for transmitting hereditary information was an aperiodic crystala crystal with atomic structures that lack translational symmetry (e.g., incommensurately modulated structures). Exact repetition during crystal growth is considered to carry insufficient "information" for heredity, whereas a substrate that lacked periodicity could pass on much more information. In his posthumous paper entitled "Geochemical Aspects of the Origin of Complex Organic Molecules on the Earth, as Precursors to Organic Life," Goldschmidt (1952) speculated that

One most important factor for selection and arrangement of adsorbed molecules is their size and shape as related to the atomic arrangement of the inorganic substratum. Besides such two-dimensional layers of more or less loosely fixed molecules there certainly must exist some analogous linear phenomena along the edges of crystals, and this would make monodimensional strings or chains of adsorbed particles. These phenomena at the surfaces of growing crystals open up possibilities for the formation of new and more complex molecular combinations and associations within such surface layers and edge strings and in interaction between the surface layers and their "basement" crystals. Many chemical reactions leading to more complicated and otherwise "improbable" molecular configurations may be initiated by processes of crystal surface catalysis ... By interaction with the "basement" crystal also such components as phosphorus, iron, calcium, magnesium, potassium, could be incorporated into the complexes of adsorbed molecules. Thus the temporary fixation of "rare" molecules into two-dimensional or monodimensional adsorption complexes on the crystal faces and crystal edges of minerals would provide the possibilities of assemblage of even complicated organic molecules.

Goldschmidt (1952) speculated that a number of minerals, including clays, could have played active roles in the origin of life.

Bernal (1949) and Cairns-Smith (1965) both argued that very fine-grained clay crystals were particularly suitable substrates. Cairns-Smith (1965) suggested that imperfections on crystal surfaces, which strongly influence their adsorptive and catalytic properties, were the source of the "genetic" information that was passed from the template to the adsorbed organic polymer. He suggested that clay crystals with high levels of strain due to misfits between layers were desirable and might limit growth in certain directions on the surface edges (Cairns-Smith, 1982, 2005).

Greenalite represents an ideal template as envisaged by Cairns-Smith $(1965,1982)$, because of, among other things, its colloidal size, rapid growth, and regular structural imperfections. Greenalite has a modulated structure with an incommensurate superlattice and displays "extreme positional disorder of the tetrahedra" (Guggenheim and Eggleton, 1998). Given the extreme structural disorder due to lattice distortions between the octahedral and tetrahedral sheets (Fig. 5), the broken edges of the greenalite nanoparticles may have displayed complex charge variations and adsorption behavior. These charges would have varied significantly with changes in $\mathrm{pH}$ as the particles traveled
FIG. 5. Diagram of the approximate crystal structure of greenalite along its $b$-axis (modified after Guggenheim and Eggleton, 1998; Capitani et al., 2009). Color images are available online.

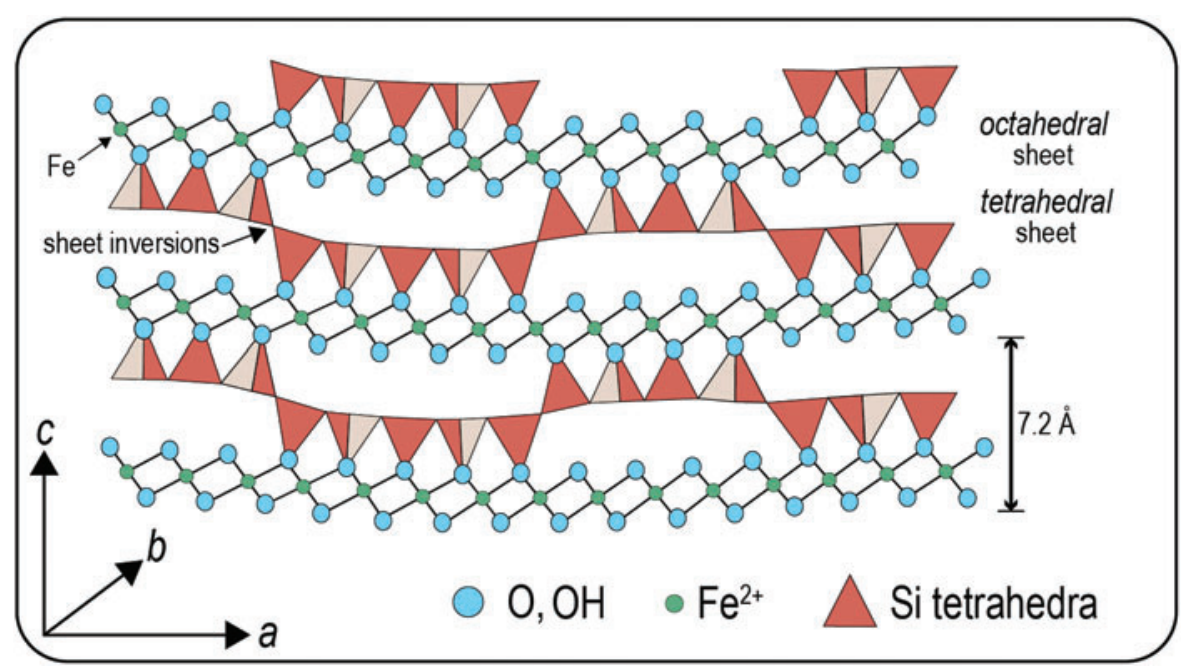


between acidic and alkaline plume solutions. Additional imperfections would be expected from rapid nucleation and precipitation in the water column, partial dissolution, recrystallization, and substitution between $\mathrm{Fe}^{2+}$ and other cations $\left(\right.$ e.g., $\left.\mathrm{Mg}^{2+}\right)$. The abundance of imperfections on the surfaces of greenalite nanoparticles may have produced regular variations on the scale of a few angstrom that could have been imparted onto adsorbed genetic polymers (Cairns-Smith, 1982).

Greenalite, apart from having a highly disordered structure, has physical dimensions that coincide with genetic material such as RNA. The misfit between the tetrahedral and octahedral sheets due to the large octahedrally coordinated $\mathrm{Fe}^{2+}$ cation results in the development of a modulated structure that resembles corrugations (Guggenheim and Eggleton, 1998). These corrugations, which are $\sim 22 \AA$ in width, manifest themselves as parallel grooves and ridges on the edges of the particles, perpendicular to the mineral cleavage (Fig. 3). These structures are potential microchannels that could have catalyzed the assembly and alignment of nucleotides into linear organic molecules such as RNA (Figs. 6 and 7). The similar width of the modulated structure $(\sim 22 \AA)$ and the diameter of helical RNA/DNA polymers $(\sim 20 \AA)$ may reflect physical constraints imposed by the original template on the assembling genetic material.

Another intriguing feature of RNA/DNA strands is that the phosphate groups in the phosphate-sugar backbone are about $7.14 \AA$ apart if the helix is unwound into a straight line. This overlaps with the distance between each T-O sheet of greenalite, which is between 7.0 and $7.2 \AA$ (Fig. 3). This could relate to the assembly of the genetic polymer. Specifically, the phosphate groups of nucleotides may have preferentially adsorbed in the structural modulation, where they attached $\sim 7.14 \AA$ apart in a repeated configuration at the intersection of the corrugation and basal plane (Fig. 7). If correct, this would suggest that the nucleotides were initially assembled as straight strands in the linear grooves on the surfaces of greenalite nanoparticles.

The assembly of straight strands may have been possible at the higher temperatures $\left(40-91{ }^{\circ} \mathrm{C}\right)$ in alkaline vent fluids. Circulation within convective cells between warmer, alkaline vent fluids and cooler, more acidic fluids may have driven repeated cycles of adsorption, assembly, and desorption ( $c f$. Ricardo and Szostak, 2009). Desorption of the phosphate group from the template surface released the organic polymers, some of which formed helical strands $(20 \AA$ wide) aligned in the corrugations and/or released from the template (Fig. 7).

It is conceivable that some of the adsorbed RNA-type strands, which were held within the linear corrugations, could themselves have acted as templates for replication of complementary strands (Fig. 7). Indeed, Cairns-Smith (1982) speculated that "perhaps the environment might have provided a catalyst for the replication of some DNA-like replicating polymer. One might think of a grooved crystal surface orienting a large-small copolymer so as to create sites with a complementary specificity." He went on to say that "a fortuitously adapted environment would be needed. The groove must be the right shape; the polymer must tend to adsorb in it; then all the monomers must shuffle into place; then they must completely polymerize; then they must come away."

Finally, if the [010] edges of the greenalite nanoparticles were the assembly site for RNA-type molecules (Fig. 7), then the thickness of the nanoparticles may have imposed a firstorder constraint on the length of the linear genetic chains. Transmission electron microscope (TEM) observations suggest that nanoparticles are between 10 and $100 \mathrm{~nm}(100$ and $1000 \AA$ ) thick and average about $50 \mathrm{~nm}(500 \AA)$. The greenalite templates could hypothetically have assembled linear RNA chains comprising 14-140 nucleotides (nt), with an average length of $70 \mathrm{nt}$. It is interesting to note that according to calculations by Manfred Eigen and his group, the optimal length of primitive genes was between 50 and $100 \mathrm{nt}$ (Eigen and Schuster, 1977; Eigen and Winkler-Ostwatitsch, 1981). This size range represents the maximal compromise between preservation of original information and mutation rate under prebiotic conditions.

\subsection{Role of greenalite in the assembly of genetic polymers and protocells}

For the first protocells to reproduce, a substrate capable of replicating genetic information is required as well as replicating vesicles for compartmentalization and transfer of hereditary information (Ricardo and Szostak, 2009). Recent experiments have shown that mixtures of single-chain amphiphiles form vesicles in solutions with modern seawater concentrations of $\mathrm{NaCl}, \mathrm{Ca}^{2+}$, and $\mathrm{Mg}^{2+}$, at $\mathrm{pH}$ values between 6.5 and $>12$
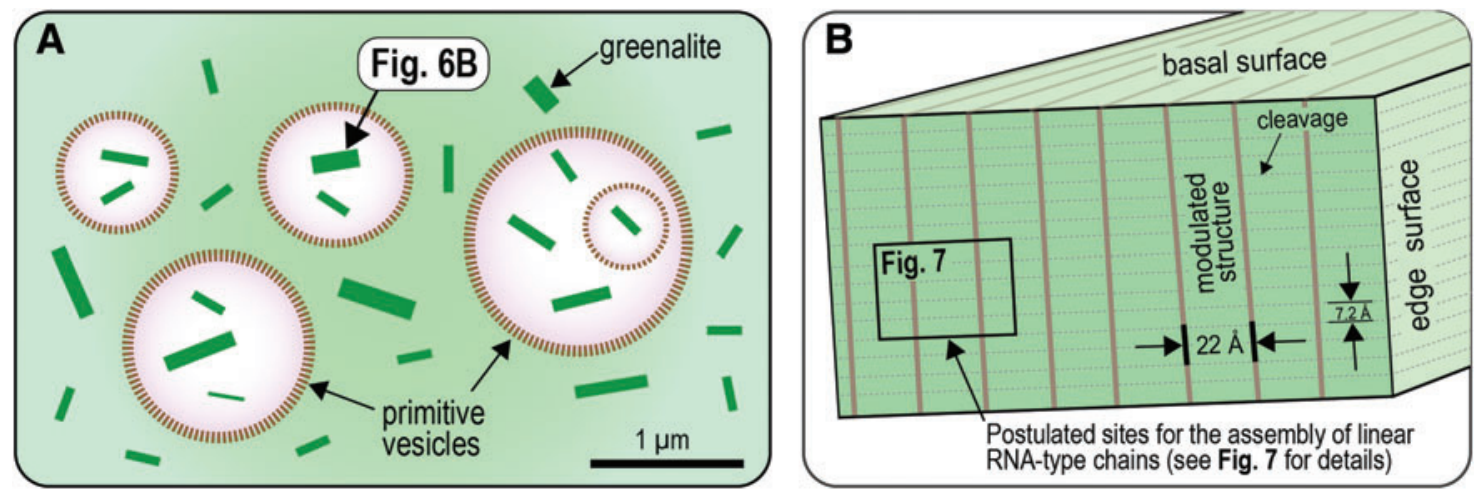

FIG. 6. (A) Diagram depicting greenalite nanoparticles encapsulated within membranous vesicles composed of amphiphilic compounds. (B) Postulated adsorption and assembly of RNA-type oligomers ( $\sim 20 \AA$ wide $)$ along modulated structures $(\sim 22 \AA$ wide) on the edges of greenalite particles (see Fig. 3). Color images are available online. 


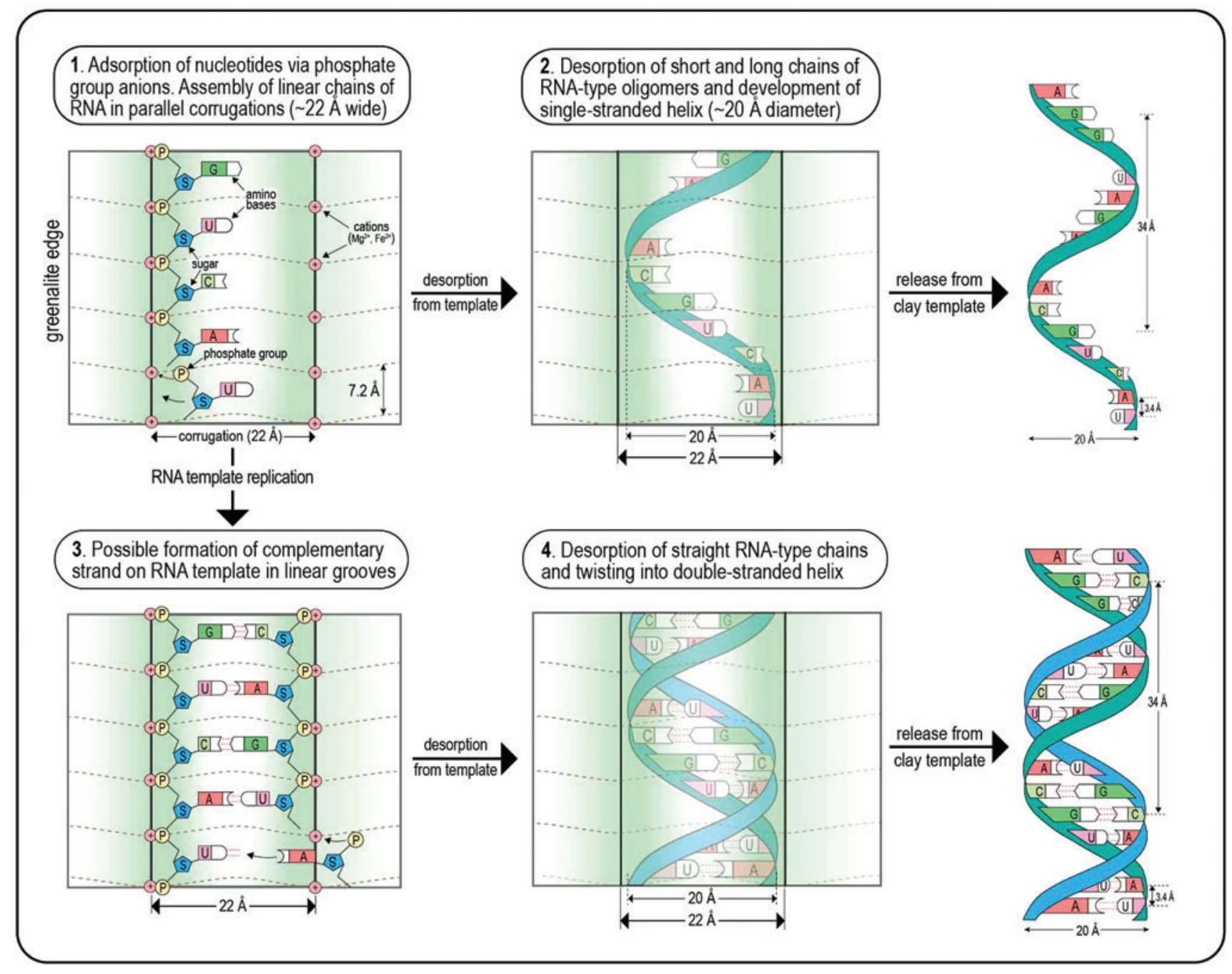

FIG. 7. Diagram showing hypothetical scenarios for the assembly of nucleotides by adsorption of phosphate groups onto metal cations (e.g., $\mathrm{Mg}^{2+}, \mathrm{Fe}^{2+}$ ) regularly spaced in the linear corrugations along the edges of greenalite nanoparticles. In this scenario, mineral surfaces may have catalyzed the assembly of a cocktail of short and long chains of organic molecules including single- and double-stranded RNA-type genetic polymers. Episodic desorption released the organic compounds from the surface adsorption sites. Color images are available online.

(Jordan et al., 2019). Vesicle growth was greatest at temperatures of $\sim 70^{\circ} \mathrm{C}$ in saline and strongly alkaline solutions, suggesting that hydrothermal alkaline conditions were conducive to the formation of protocells (Jordan et al., 2019).

Hanczyc et al. (2003) showed that the addition of minute particles of clay (e.g., montmorillonite) accelerated the conversion of fatty acid micelles to vesicles in alkaline solutions by a factor of 100 . It is possible that the presence of greenalite nanoparticles may have had a similar effect, increasing the rate of vesicle assembly in alkaline plumes. Because of the minute size of greenalite nanoparticles, they could have become enclosed within the semipermeable membranes of the vesicles (Fig. 6), stopping the products of surface-mediated chemical reactions from being dispersed into seawater. Indeed, the encapsulation of nanoparticles would explain how RNA-based chains synthesized on mineral templates came to reside inside primitive vesicles ( $c f$. Hanczyc et al., 2003).

The linear genetic polymers may have been desorbed from the template in response to changes in chemistry (e.g., temperature, $\mathrm{pH}$ ) and consequently enclosed within the protocell. With the migration of smaller activated nucleotides and building blocks across the semipermeable membranes into the protocell (Mansy et al., 2008), the greenalite nanotemplates could have facilitated the assembly of a new generation of organic molecules. Slight changes in the adsorptive properties of the mineral substrate may have passed on subtle changes to the assembling genetic polymers. The trapped greenalite templates therefore may have acted as genetic replicators, producing multiple generations of RNAbased polymers that accumulated within the membranes. At some point, greenalite became redundant as genetic replication was taken over by organic templates.

Replication of protocells containing greenalite and RNAbased molecules may have occurred via a mechanism of coupled growth and division of vesicles (Zhu and Szostak, 2009; Szostak, 2017). It has been shown experimentally that large spherical vesicles composed of multiple layers of fatty acid can be transformed into long threadlike vesicles. These 
threads, if subjected to modest shear forces, can be divided into multiple daughter vesicles. This mechanism can also distribute encapsulated RNA molecules, representing a primitive genome, from the parent to daughter vesicles (Zhu and Szostak, 2009). The presence of encapsulated greenalite templates would have resulted in faster replication of genetic material leading to an increase in the osmotic pressure membrane growth, promoting division into daughter cells. Such a process could have driven growth and division of primitive cell membranes, potentially replicating daughter membranes with greenalite templates capable of producing new genetic material. A possible environmental setting for this mechanism is the alkaline vent plumes above serpentinizing ultramafic rocks, where carbon-bearing fluids continuously mixed in convection cells with the larger, more acidic plumes and seawater.

Prior to the replication of complementary strands by RNA templates, a mineral surface was likely required to form genetic information within protocells. The transfer of a limited number of greenalite nanoparticles in the parent cell to daughter cells would eventually lead to a situation whereby later generations of daughter cells lacked greenalite templates and therefore the ability to form and pass on their own genetic information. This limiting process was eventually overcome when protocells attained the ability to duplicate their own genetic material without a mineral template. At this point, greenalite templates were no longer necessary for replication of genetic information.

\subsection{Dispersal of greenalite nanoparticles in vent plumes}

Given their minute size, greenalite nanoparticles probably remained in suspension for years (Rasmussen et al., 2019b). Even in today's ocean, hydrothermal plumes can transport $>450 \mathrm{~nm}$ particles $>4300 \mathrm{~km}$ (Fitzsimmons et al., 2017). The emission of hot vent fluids into cooler seawater probably generated convective cells that caused resuspension of claylike nanoparticles, adding significantly to their residence time. A possible consequence would be a long and complex history of particle-fluid interaction during changes in seawater chemistry (e.g., $\mathrm{pH}$, redox, temperature) as the particles traveled between acidic- and alkaline-dominated vent plume water, and seawater. In the dynamic mixing zones, differences in $\mathrm{pH}$ and chemistry between the interior of the protocell and seawater are likely to have caused the transfer of protons and cations across the initially leaky vesicles, driven by electrochemical and osmotic forces.

\subsection{Greenalite in terrestrial hot springs and pools}

Earth's land surface is also a plausible setting for the emergence of life, particularly terrestrial geothermal springs and ponds (Fig. 8) (Mulkidjanian et al., 2012; Damer and Deamer, 2015). Although our model is based on observations from submarine hydrothermally derived sediments (i.e., BIFs), it is possible that greenalite nanoparticles also formed around hydrothermal springs on land. There are few, if any, examples of Archean terrestrial hot spring deposits, so it is not possible to search the rock record for hydrothermal precipitates. However, the hydrothermal leaching of mafic volcanic rocks on land by anoxic meteoric fluids may also have released $\mathrm{Fe}^{2+}$ and $\mathrm{SiO}_{2}$, that precipitated as greenalite nanoparticles in the hot springs, pools and lakes fed by hydrothermal effluent (scenario 3 in Fig. 8).

If greenalite nanoparticles formed in subaerial hydrothermal pools, it is possible that they played a similar role to that proposed for submarine vent plumes, serving as readily available templates for concentration and assembly of prebiotic chemicals produced in terrestrial hot springs and pools. The transportation of terrestrially synthesized biochemical compounds and discharge into the shallow ocean also represents a possible mixing site with greenalite nanoparticles generated from submarine vent systems and carried as suspended particles into coastal environments (scenario 2 in Fig. 8).

\section{Testing Greenalite as Template in the Origin of Life}

\subsection{Experimentation}

Greenalite has not been studied previously in origins-oflife experiments, in contrast to montmorillonite, which is the most widely used clay mineral (Ferris et al., 1996; Ertem and Ferris, 1998, 2000; Huang and Ferris, 2003, 2006; Joshi

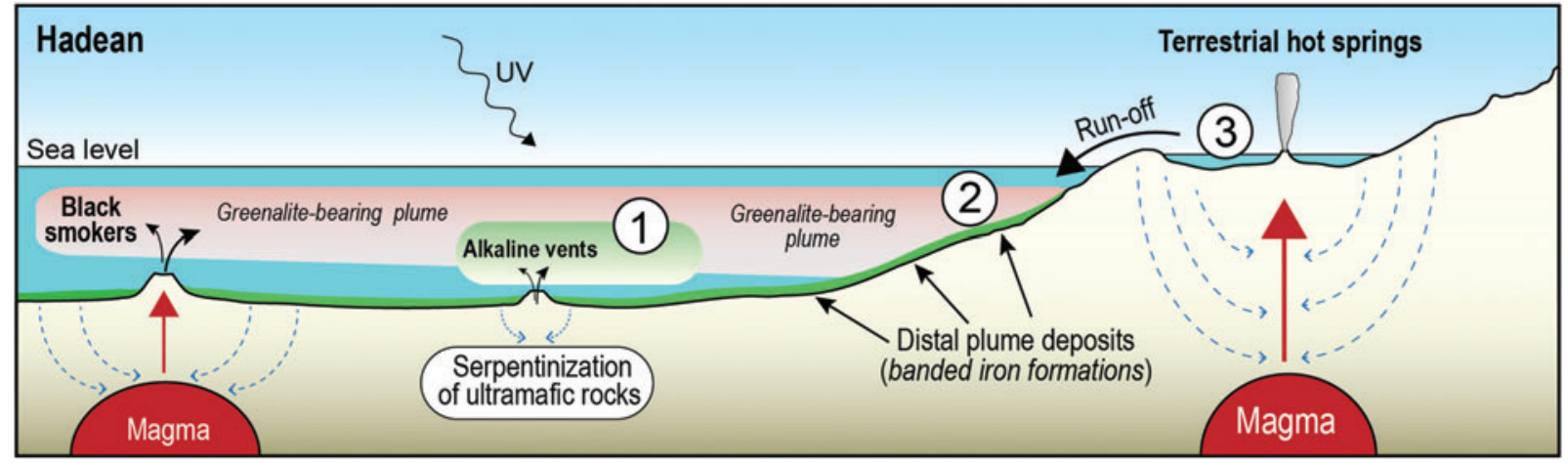

FIG. 8. Potential environments where greenalite templates may have promoted polymerization and vesicle assembly. Scenario 1: mixing of hot, acidic, metal-rich plumes with organic-rich alkaline plumes. Scenario 2: suspended greenalite nanoparticles in submarine hydrothermal plumes mix with biochemical compounds discharged from terrestrial springs. Scenario 3: terrestrially generated greenalite and biochemical compounds combine in hot springs and pools. Color images are available online. 
et al., 2007, 2009). If our hypothesis has merit, then greenalite should rival, and perhaps exceed, montmorillonite as a template for the assembly of genetic polymers and the growth of protocells.

To test our hypothesis, we propose a series of experiments to investigate the following:

(1) the adsorption and concentration of RNA-type monomers on the surfaces of greenalite and other minerals (e.g., montmorillonite).

(2) the catalytic behavior of greenalite in the oligomerization of activated RNA monomers ( $c f$. Ferris et al., 1996).

(3) whether greenalite promotes the formation of shortto long-chained organic molecules (separate from RNA-type chains).

(4) the ability of greenalite nanoparticles to catalyze the formation of primitive membranes in fatty acid solutions (cf. Hanczyc et al., 2003).

(5) the encapsulation of greenalite nanoparticles during vesicle growth.

\subsection{Primordial greenalite on Mars?}

Given its mode of formation and distribution on early Earth, it is possible that greenalite was a common product of anoxic hydrothermal alteration of basaltic/ultramafic igneous rocks, that may have started to form soon after the first oceans condensed. The rock record of greenalite (Fig. 1) shows that it is present in some of the oldest well-preserved sedimentary rocks: $3.45 \mathrm{Ga}$ cherts from Marble Bar in the Pilbara Craton, Australia (Rasmussen et al., 2014; Muhling and Rasmussen, 2020). However, it is unlikely to be found in rocks $>3.5 \mathrm{Ga}$ on Earth because of the high levels of metamorphism and deformation.

In contrast, clay minerals $>3.5 \mathrm{Ga}$ are preserved on Mars (Ehlmann et al., 2011; Michalski et al., 2017, 2018; Sasselov et al., 2020). A potential test of the broader availability of greenalite as a template for prebiotic synthesis on wet rocky planets is its presence in ancient hydrothermal sediments on Mars. It is likely that favorable environments for greenalite growth probably existed on the surface of Mars during its first billion years (e.g., Eridania Basin; Michalski et al., 2017). This can potentially be confirmed through the use of orbital spectral data and in situ analysis of clay minerals in sedimentary deposits on the martian surface (e.g., during the Mars 2020 mission).

\section{Conclusions}

We present a hypothesis centered on the precipitation of greenalite nanoparticles that links hydrothermal vent environments with clay-like mineral templates implicated in RNA-based synthesis. Greenalite probably precipitated in hydrothermal vent plumes soon after the development of an ocean, forming a limitless supply of free-floating clay nanotemplates. Their highly disordered lattice and development of parallel microchannels $(\sim 22 \AA$ wide) may have provided an ideal template for the concentration and assembly of linear genetic polymers ( $20 \AA$ in diameter). We envisage that the mixing of high-temperature acidic metalrich plumes with alkaline, organic-bearing plumes not only brought together chemical compounds from both vent sys- tems but also triggered the precipitation of greenalite nanoparticles at temperatures $<90^{\circ} \mathrm{C}$. The nanoparticles could have provided templates for the assembly of genetic organic polymers and also accelerated the growth of primitive membranes. Their minute size allowed them to be enclosed in vesicles, trapping catalytic mineral surfaces within the primitive membranes. The particles would have been suspended in the water column for years and acted to transport primitive cells and early life throughout the ocean to colonize new habitats. Although our observations are based on submarine hydrothermal sediments, it is likely that hydrothermal leaching of basalts in subaerial environments also produced greenalite on early Earth and that it could have played a similar role in shallow hot springs and pools in the key steps toward the development of life.

\section{Acknowledgments}

B.R. and J.R.M. received support from Australian Research Council grants DP140100512 and DP190102237. W.W.F. acknowledges support of the Simons Foundation Collaboration on the Origins of Life. Support for the acquisition of the scientific drill cores was provided by the Agouron Institute and NASA Astrobiology Program. Electron microscopy was performed at the Centre for Microscopy, Characterisation and Analysis at the University of Western Australia, a node of Microscopy Australia, funded from university and government sources. We thank S. Bengtson for comments on an early version of the manuscript and two anonymous journal reviewers for their helpful comments.

\section{Author Disclosure Statement}

No competing financial interests exist.

\section{References}

Aldersley, M.F., Joshi, P.C., Price, J.D., and Ferris, J.P. (2011) The role of montmorillonite in its catalysis of RNA synthesis. Appl Clay Sci 54:1-14.

Arndt, N.T., and Nisbet, E.G. (2012) Processes on the young Earth and the habitats of early life. Ann Rev Earth Planet Sci 40:521-49.

Arrhenius, G.O. (2003) Crystals and life. Helvetica Chimica Acta 86:1569-1586.

Bailey, S.W. (1980) Summary of recommendations of AIPEA nomenclature committee on clay minerals. Am Mineral 65:1-7.

Baross, J.A., and Hoffman, S.E. (1985) Submarine hydrothermal vents and associated gradient environments as sites for the origin and evolution of life. Orig Life Evol Biosph 15: 327-345.

Bekker, A., Planavsky, N., Krapež, B., Rasmussen, B., Hofmann, A., Slack, J.F., Konhauser, K.O., and Rouxel, O.J. (2014) Iron formations: their origins and implications for ancient seawater chemistry. In Treatise on Geochemistry, edited by H.D. Holland and K.K. Turekian, Elsevier, Oxford, pp 561-628.

Bennett, R.H., Bryant, W.R., and Keller, G.H. (1981) Clay fabric of selected submarine sediments: fundamental properties and models. J Sediment Petrol 51:217-232.

Bennett, R.H., Bryant, W.R., and Hulbert, M.H. (1991) Microstructure of Fine-Grained Sediments: From Mud to Shale, Springer-Verlag, New York.

Bernal, J.D. (1949) The physical basis of life. Proc Phys Soc A 62:537-558. 
Beukes, N.J., and Gutzmer, J. (2008) Origin and paleoenvironmental significance of major iron formations at the ArcheanPaleoproterozoic boundary. Rev Econ Geol 15:5-47.

Bickle, M.J. (1978) Heat loss from the Earth: a constraint on Archaean tectonics from the relation between geothermal gradients and the rate of heat production. Earth Planet Sci Lett 40:301-315.

Biondi, E., Branciamore, S., Maurel, M.-C., and Gallori, E. (2007) Montmorillonite protection of an UV-irradiated hairpin ribozyme: evolution of the RNA world in a mineral environment. BMC Evol Biol 7, doi:10.1186/1471-2148-7S2-S2.

Cairns-Smith, G. (1965) The origin of life and the nature of the primitive gene. $J$ Theor Biol 10:53-88.

Cairns-Smith, G. (1982) Genetic Takeover and the Mineral Origins of Life, Cambridge University Press, Cambridge, UK.

Cairns-Smith, G. (2005) Sketches for a mineral genetic material. Elements 1:157-161.

Canfield, D.E. (2005) The early history of atmospheric oxygen. Annu Rev Earth Planet Sci 33:1-36.

Capitani, G.C., Stixrude, L., and Mellini, M. (2009) Firstprinciples energetics and structural relaxation of antigorite. Am Mineral 94:1271-1278.

Charlou, J.L., Donval, J.P., Fouquet, Y., Jean-Baptiste, P., and Holm, N. (2002) Geochemistry of high $\mathrm{H}_{2}$ and $\mathrm{CH}_{4}$ vent fluids issuing from ultramafic rocks at the Rainbow hydrothermal field (3614N, MAR). Chem Geol 191:345359.

Cody, G.D., Boctor, N.Z., Filley, T.R., Hazen, R.M., Scott, J.H., Sharma, A., and Yoder, H.S., Jr. (2000) Primordial carbonylated iron-sulfur compounds and the synthesis of pyruvate. Science 289:1337-1340.

Corliss, J.B., Dymond, J., Gordon, L.I., Edmond, J.M., von Herzen, R.P., Ballard, R.D., Green, K., Williams, D., Bainbridge, A., Crane, K., and van Andel, T.H. (1979) Submarine thermal springs on the Galapagos Rift. Science 203:10731083.

Corliss, J.B., Baross, J.A., and Hoffmann, S.E. (1981) An hypothesis concerning the relationship between submarine hot springs and the origin of life on Earth. Oceanologica Acta 4: 59-69.

Damer, B., and Deamer, D. (2015) Coupled phases and combinatorial selection in fluctuating hydrothermal pools: a scenario to guide experimental approaches to the origin of cellular life. Life 5:872-887.

Deamer, D.W., and Georgiou, C.D. (2015) Hydrothermal conditions and the origin of cellular life. Astrobiology 15:10911095.

Deirieh, A., Chang, I.Y., Whittaker, M.L., Weigand, S., Keane, D., Rix, J., Germaine, J.T., Joester, D., and Flemings, P.B. (2018) Particle arrangements in clay slurries: the case against the honeycomb structure. Appl Clay Sci 152: 166-172.

Derry, L.A., and Jacobsen, S.B. (1990) The chemical evolution of Precambrian seawater: evidence from REEs in banded iron formations. Geochim Cosmochim Acta 54: 2965-2977.

Ehlmann, B.L., Mustard, J.F., Murchie, S.L., Bibring, J-P., Meunier, A., Fraeman, A.A., and Langevin, Y. (2011) Subsurface water and clay mineral formation during the early history of Mars. Nature 479:53-60.

Eigen, M., and Schuster, P. (1977) The hypercycle. Naturwissenschaften 64:541-565.
Eigen, M., and Winkler-Ostwatitsch, R. (1981) Transfer-RNA, an early gene? Naturwissenschaften 68:282-292.

Elderfield, H., and Schultz, A. (1996) Mid-ocean ridge hydrothermal fluxes and the chemical composition of the ocean. Annu Rev Earth Planet Sci 24:191-224.

Ertem, G., and Ferris, J.P. (1998) Formation of RNA oligomers on montmorillonite: site of catalysis. Orig Life Evol Biosph 28:485-499.

Ertem, G., and Ferris, J.P. (2000) Sequence- and regio-selectivity in the montmorillonite-catalyzed synthesis of RNA. Orig Life Evol Biosph 30:411-422.

Ferris, J.P. (2002) Montmorillonite catalysis of 30-50 mer oligonucleotides: laboratory demonstration of potential steps in the origin of the RNA world. Orig Life Evol Biosph 32:311332.

Ferris, J.P. (2005) Catalysis and prebiotic synthesis. Rev Mineral Geochem 59:187-210.

Ferris, J.P., and Ertem, G. (1992) Oligomerization of ribonucleotides on montmorillonite: reaction of the 5'-phosphorimidazolide of adenosine. Science 257:1387-1389.

Ferris, J.P., Ertem, G., and Agarwal, V.K. (1989a) Mineral catalysis of the formation of dimers of 5'-AMP in aqueous solution: the possible role of montmorillonite clays in the prebiotic synthesis of RNA. Orig Life Evol Biosph 19:165-178.

Ferris, J.P., Ertem, G., and Agarwal, V.K. (1989b) The adsorption of nucleotides and polynucleotides on montmorillonite clay. Orig Life Evol Biosph 19:153-164.

Ferris, J.P., Hill, A.R., Jr., Liu, R., and Orgel, L.E. (1996) Synthesis of long prebiotic oligomers on mineral surfaces. Nature 381:59-61.

Feuillie, C., Daniel, I., Michot, L.J., and Pedreira-Segade, U. (2013) Adsorption of nucleotides onto $\mathrm{Fe}-\mathrm{Mg}-\mathrm{Al}$ rich swelling clays. Geochim Cosmochim Acta 120:97-108.

Fischer, W.W., and Knoll, A.H. (2009) An iron shuttle for deepwater silica in Late Archean and early Paleoproterozoic iron formation. Geol Soc Am Bull 121:222-235.

Fitzsimmons, J.N., John, S.G., Marsay, C.M., Hoffman, C.L., Nicholas, S.L., Toner, B.M., German, C.R., and Sherrell, R.M. (2017) Iron persistence in a distal hydrothermal plum supported by dissolved-particulate exchange. Nat Geosci 10: 195-201.

Franchi, M., Bramanti, E., Bonzi, L.M., Orioli, P.L., Vettori, C., and Gallori, E. (1999) Clay-nucleic acid complexes: characteristics and implications for the preservation of genetic material in primeval habitats. Orig Life Evol Biosph 29:297315.

Franchi, M., Ferris, J.P., and Gallori, E. (2003) Cations as mediators of the adsorption of nucleic acids on clay surfaces in prebiotic environments. Orig Life Evol Biosph 33: $1-16$.

Francisco, P.C.M., Mitsui, S., Ishidera, T., Tachi, Y., Doi, R., and Shiwaku, H. (2020) Interaction of $\mathrm{Fe}^{\mathrm{II}}$ and $\mathrm{Si}$ under anoxic and reducing conditions: structural characteristics of ferrous silicate co-precipitates. Geochim Cosmochim Acta 270:1-20.

German, C.R., and Von Damm, K.L. (2003) Hydrothermal processes. In The Oceans and Marine Geochemistry, edited by H. Elderfield, Treatise on Geochemistry Vol. 6, ElsevierPergamon, Oxford, pp 181-222.

Gilbert, W. (1986) The RNA world. Nature 319:618.

Goldschmidt, V.M. (1952) Geochemical aspects of the origin of complex organic molecules on the Earth, as precursors to organic life. New Biol 12:97-105. 
Greenwell, H.C., and Coveney, P.V. (2006) Layered double hydroxide minerals as possible prebiotic information storage and transfer compounds. Orig Life Evol Biosph 36:13-37.

Guggenheim, S., and Eggleton, R.A. (1998) Modulated crystal structures of greenalite and caryopilite: a system with long range, in-plane structural disorder in the tetrahedra sheet. Can Mineral 36:163-179.

Halevy, I., and Bachan, A. (2017) The geologic history of seawater pH. Science 355:1069-1071.

Halevy, I., Alesker, M., Schuster, E., Popovitz-Biro, R., and Feldman, Y. (2017) A key role for green rust in the Precambrian oceans and the genesis of iron formations. Nat Geosci 10:135-139.

Hanczyc, M.M., Fujikawa, S.M., and Szostak, J.W. (2003) Experimental models of primitive cellular compartments: encapsulation, growth, and division. Science 302:618-622.

Hazen, R.M., and Sverjensky, D.A. (2010) Mineral surfaces, geochemical complexities, and the origins of life. Cold Spring Harb Perspect Biol 2, doi:10.1101/cshperspect.a002162.

Huang, W., and Ferris, J.P. (2003) Synthesis of 35-40 mers of RNA oligomers from unblocked monomers. A simple approach to the RNA world. Chem Commun 12:1458-1459.

Huang, W., and Ferris, J.P. (2006) One-step, regioselective synthesis of up to 50-mers of RNA oligomers by montmorillonite catalysis. J Am Chem Soc 128:8914-8919.

Huber, C., and Wächtershäuser, G. (1997) Activated acetic acid by carbon fixation on $(\mathrm{Fe}, \mathrm{Ni}) \mathrm{S}$ under primordial conditions. Science 276:245-247.

Huber, C., and Wächtershäuser, G. (1998) Peptides by activation of amino acids on (Fe,Ni)S surfaces: implications for the origin of life. Science 281:670-672.

Huber, C., and Wächtershäuser, G. (2006) a-hydroxy and a-amino acids under possible Hadean, volcanic origin of life conditions. Science 314:630-632.

Isley, A.E. (1995) Hydrothermal plumes and the delivery of iron to banded iron formation. J Geol 103:169-185.

Isley, A.E., and Abbott, D.H. (1999) Plume-related mafic volcanism and the deposition of banded iron formation. $J$ Geophys Res 104:15461-15477.

Jacobsen, S.B., and Pimentel-Klose, M.L. (1988) A Nd isotopic study of the Hamersley and Michipicoten banded iron formations: the source of REE and Fe in Archean oceans. Earth Planet Sci Lett 87:29-44.

Jelavic, S., Tobler, D.J., Hassenkam, T., De Yoreo, J.J., Stipp, S.L.S., and Sand, K.K. (2017) Prebiotic RNA polymerisation: energetics of nucleotide adsorption and polymerisation on clay mineral surfaces. Chem Commun 53:12700-12703.

Jiang, C.Z., and Tosca, N.J. (2019) Fe(II)-carbonate precipitation kinetics and the chemistry of anoxic ferruginous seawater. Earth Planet Sci Lett 506:231-242.

Johnson, J.E., Muhling, J.R., Cosmidis, J., Rasmussen, B., and Templeton, A.S. (2018) Low-Fe(III) greenalite was a primary mineral from Neoarchean oceans. Geophys Res Lett 45, doi: 10.1002/2017GL076311.

Jordan, S.F., Rammu, H., Zheludev, I.N., Hartley, A.M., Maréchal, A., and Lane, N. (2019) Promotion of protocell self-assembly from mixed amphiphiles at the origin of life. Nature Ecol Evol 3:1705-1714.

Joshi, P.C., Pitsch, S., and Ferris, J.P. (2007) Selectivity of montmorillonite catalyzed prebiotic reactions of $\mathrm{D}, \mathrm{L}$-nucleotides. Orig Life Evol Biosph 37:3-26.

Joshi, P.C., Aldersley, M.F., Delano, J.W., and Ferris, J.P. (2009) Mechanism of montmorillonite catalysis in the formation of RNA oligomers. J Am Chem Soc 131:13369-13374.
Joyce, G.F. (2002) The antiquity of RNA-based evolution. Nature 418:214-221.

Kanavarioti, A., Monnard, P-L., and Deamer, D.W. (2001) Eutectic phases in ice facilitate nonenzymatic nucleic acid synthesis. Astrobiology 1:271-281.

Kase, Y., Sato, M., Nishida, N., Ito, N., Mukti, M., Ikehara, K., and Takizawa, S. (2016) The use of microstructures for discriminating turbiditic and hemipelagic muds and mudstones. Sedimentology 63:2066-2086.

Kelley, D.S., Karson, J.A., Blackman, D.K., Früh-Green, G.L., Butterfield, D.A., Lilley, M.D., Olson, E.J., Schrenk, M.O., Roe, K.K., Lebon, G.T., Rivizzigno, P., and The AT3-60 Shipboard Party. (2001) An off-axis hydrothermal vent field near the Mid-Atlantic Ridge at 30N. Nature 412: 145-149.

Kelley, D.S., Karson, J.A., Früh-Green, G.L., Yoerger, D.R., Shank, T.M., Butterfield, D.A., Hayes, J.M., Schrenk, M.O., Olson, E.J., Proskurowski, G., Jakuba, M., Bradley, A., Larson, B., Ludwig, K., Glickson, D., Buckman, K., Bradley, A.S., Brazelton, W.J., Roe, K., Elend, M.J., Delacour, A., Bernasconi, S.M., Lilley, M.D., Baross, J.A., Summons, R.E., and Sylva, S.P. (2005) A serpentinitehosted ecosystem: the Lost City hydrothermal field. Science 307:1428-1434.

Kitadai, N., Nakamura, R., Yamamoto, M., Takai, K., Li, Y., Yamaguchi, A., Gilbert, A., Ueno, Y., Yoshida, N., and Oono Y. (2018) Geoelectrochemical CO production: implications for the autotrophic origin of life. Sci Adv 4, doi:10.1126/ sciadv.aao7265.

Klein, C. (2005) Some Precambrian banded iron-formations (BIFs) from around the world: their age, geologic setting, mineralogy, metamorphism, geochemistry, and origin. Am Mineral 90:1473-1499.

Konhauser, K.O., Planavsky, N.J., Hardisty, D.S., Robbins, L.J., Warchola, T.J., Haugaard, R., Lalonde, S.V., Partin, C.A., Oonk, P.B.H., and Tsikos, H. (2017) Iron formations: a global record of Neoarchaean to Palaeoproterozoic environmental history. Earth-Sci Rev 172:140-177.

Konn, C., Charlou, J.L., Holm, N.G., and Mousis O. (2015) The Production of methane, hydrogen, and organic compounds in ultramafic-hosted hydrothermal vents of the Mid-Atlantic Ridge. Astrobiology 15:381-399.

Lane, N., Allen, J.F., and Martin, W. (2010) How did LUCA make a living? Chemiosmosis in the origin of life. Bioessays 32:271-280.

Li, Y., Kitadai, N., and Nakamura, R. (2018) Chemical diversity of metal sulfide minerals and its implications for the origin of life. Life 8, doi:10.3390/life8040046.

Lowell, R.P., and Keller, S.M. (2003) High-temperature seafloor hydrothermal circulation over geologic time and $\mathrm{Ar}-$ chean banded iron formations. Geophys Res Lett 30, doi: 10.1029/2002GL016536.

Ludwig, K.A., Kelley, D.S., Shen, C., Cheng, H., and Edwards, R.L. (2005) U/Th geochronology of carbonate chimneys at the Lost City hydrothermal field. Eos Trans AGU 86:V51B1487.

Mansy, S.S., Schrum, J.P., Krishnamurthy, M., Tobe, S., Treco, D.A., and Szostak, J.W. (2008) Template-directed synthesis of a genetic polymer in a model protocell. Nature 454:122-126.

Martin, W., Baross, J., Kelley, D., and Russell, M.J. (2008) Hydrothermal vents and the origin of life. Nat Rev Microbiol 6:805-814.

Martin, W.F., Sousa, F.L., and Lane, N. (2014) Energy at life's origin. Science 344:1092-1093. 
Menez, B., Pisapia, C., Andreani, M., Jamme, F., Vanbellingen, Q.P., Brunelle, A., Richard, L., Dumas, P., and Réfrégiers, M. (2018) Abiotic synthesis of amino acids in the recesses of the oceanic lithosphere. Nature 564:59-63.

Meunier, A., Petit, S., Cockell, C.S., El Albani, A., and Beaufort, D. (2010) The Fe-rich clay microsystems in basaltkomatiite lavas: importance of Fe-smectites for pre-biotic molecule catalysis during the Hadean eon. Orig Life Evol Biosph 40:253-272.

Michalski, J.R., Dobrea, E.Z.N., Niles, P.B., and Cuadros, J. (2017) Ancient hydrothermal seafloor deposits in Eridania basin on Mars. Nat Commun 8, doi:10.1038/ncomms15978.

Michalski, J.R., Onstott, T.C., Mojzsis, S.J., Mustard, J., Chan, Q.H.S, Niles, P.B., and Johnson, S.S. (2018) The martian subsurface as a potential window into the origin of life. Nature Geosci 11:21-26.

Mielke, R.E., Russell, M.J., Wilson, P.R., McGlynn, S.E., Coleman, M., Kidd, R., and Kanik, I. (2010) Design, fabrication, and test of a hydrothermal reactor for origin-of-life experiments. Astrobiology 10:799-810.

Miller, S.L., and Bada, J.L. (1988) Submarine hot springs and the origin of life. Nature 334:609-611.

Muhling, J.R., and Rasmussen, B. (2020) Widespread deposition of greenalite to form banded iron formations before the Great Oxidation Event. Precambrian Res 339, doi:10.1016/ j.precamres.2020.105619.

Mulkidjanian, A.Y., Bychkov, A.Yu., Dibrova, D.V., Galperine, M.Y., and Koonine, E.V. (2012) Origin of first cells at terrestrial, anoxic geothermal fields. Proc Natl Acad Sci USA 109:821-830.

Ooka, H., McGlynn, S.E., and Nakamura, R. (2018) Electrochemistry at deep-sea hydrothermal vents: utilization of the thermodynamic driving force towards the autotrophic origin of life. Chem Electro Chem 6:1316-1323.

Parsons, I., Lee, M.R., and Smith, J.V. (1998) Biochemical evolution II: origin of life in tubular microstructures on weathered feldspar surfaces. Proc Natl Acad Sci USA 95: 15173-15176.

Pedreira-Segade, U., Feuillie, C., Pelletier, M., Michot, L.J., and Daniel, I. (2016) Adsorption of nucleotides onto ferromagnesian phyllosilicates: significance for the origin of life. Geochim Cosmochim Acta 176:81-95.

Proskurowski, G., Lilley, M.D., Seewald, J.S., Früh-Green, G.L., Olson, E.J., Lupton, J.E., Sylva, S.P., and Kelley, D.S. (2008) Abiogenic hydrocarbon production at Lost City hydrothermal field. Science 319:604-607.

Rao, M., Odom, D.G., and Orò, J. (1980) Clays in prebiological chemistry. J Mol Evol 15:317-331.

Rasmussen, B., Krapez, B., and Muhling, J.R. (2014) Hematite replacement of iron-bearing precursor sediments in the 3.46b.y.-old Marble Bar Chert, Pilbara craton, Australia. Geol Soc Am Bull 126:1245-1258.

Rasmussen, B., Krapez, B., Muhling, J.R., and Suvorova, A.A. (2015) Precipitation of iron silicate nanoparticles in early Precambrian oceans marks Earth's first iron age. Geology 43: 303-306.

Rasmussen, B., Muhling, J.R., Suvorova, A., and Krapez, B. (2017) Greenalite precipitation linked to the deposition of banded iron formations downslope from a late Archaean carbonate platform. Precambrian Res 290:49-62.

Rasmussen, B., Muhling, J.R., Tosca, N.J., and Tsikos, H. (2019a) Evidence for anoxic shallow oceans $2.45 \mathrm{Ga}$ : implications for the rise of oxygenic photosynthesis. Geology 47:622-626.
Rasmussen, B., Muhling, J.R., and Fischer, W.W. (2019b) Evidence from laminated chert in banded iron formations for deposition by gravitational settling of iron-silicate muds. Geology 47:167-170.

Ricardo, A., and Szostak, J.W. (2009) Life on Earth. Sci Am 301:54-61.

Roldan, A., Hollingsworth, N., Roffey, A., Islam, H.-U., Goodall, J.B.M., Catlow, C.R.A., Darr, J.A., Bras, W., Sankar, G., Holt, K.B., Hogarth, G., and de Leeuw, N.H. (2015) Bio-inspired $\mathrm{CO}_{2}$ conversion by iron sulfide catalysts under sustainable conditions. Chem Comm 51:7501-7504.

Russell, M.J. (2003) On the importance of being alkaline. Science 302:580-581.

Russell, M.J. (2007) The alkaline solution to the emergence of life: energy, entropy and early evolution. Acta Biotheor 55: 133-179.

Russell, M.J. (2018) Green rust: the simple organizing 'seed' of all life? Life 8, doi:10.3390/life8030035.

Russell, M.J., and Hall, A.J. (1997) The emergence of life from iron monosulphide bubbles at a submarine hydrothermal redox and pH front. J Geol Soc London 154:377-402.

Russell, M.J., Hall, A.J., Boyce, A.J., and Fallick, A.E. (2005) On hydrothermal convection systems and the emergence of life. Econ Geol 100:419-438.

Sasselov, D.D., Grotzinger, J.P., and Sutherland, J.D. (2020) The origin of life as a planetary phenomenon. $S c i A d v$ 6, doi: 10.1126/sciadv.aax3419.

Schrenk, M.O., Brazelton, W.J., and Lang, S.Q. (2013) Serpentinization, carbon, and deep life. Rev Mineral Geochem 75:575-606.

Schrödinger, E. (1944) What is Life? Cambridge University Press, Cambridge, UK.

Siever, R. (1992) The silica cycle in the Precambrian. Geochim Cosmochim Acta 56:3265-3272.

Sleep, N.H. (2010) The Hadean-Archaean environment. In Additional Perspectives on the Origins of Life, edited by D. Deamer and J.W. Szostak, Cold Spring Harbor Laboratory Press, Cold Spring Harbor, NY.

Sojo, V., Herschy, B., Whicher, A., Camprubi, E., and Lane, N. (2016) The origin of life in alkaline hydrothermal vents. Astrobiology 16:181-197.

Szostak, J.W. (2017) The narrow road to the deep past: in search of the chemistry of the origin of life. Angew Chem Int Ed 56:11037-11043.

Templeton, A.S., and Ellison, E.T. (2020) Formation and loss of metastable brucite: does Fe(II)-bearing brucite support microbial activity in serpentinizing ecosystems? Phil Trans $R$ Soc A 378, doi:10.1098/rsta.2018.0423.

Tombácz, E., and Szekeres, M. (2006) Surface charge heterogeneity of kaolinite in aqueous suspension in comparison with montmorillonite. Appl Clay Sci 34:105-124

Tosca, N.J., Guggenheim, S., and Pufahl, P.K. (2016) An authigenic origin for Precambrian greenalite: implications for iron formation and the chemistry of ancient seawater. Geol Soc Am Bull 128:511-530.

Tosca, N.J., Jiang, C.Z., Rasmussen, B., and Muhling, J.R. (2019) Products of the iron cycle on the early Earth. Free Rad Biol Med 140:138-150.

Tutolo, B.M., Evans, B.W., and Kuehner, S.M. (2019) Serpentine-hisingerite solid solution in altered ferroan peridotite and olivine gabbro. Minerals 9, doi:10.3390/min9010047.

Westall, F., Hickman-Lewis, K., Hinman, N., Gautret, P., Campbell, K.A., Bréhéret, J.G., Foucher, F., Hubert, A., Sorieul, S., Dass, A.V., Kee, T.P., Georgelin, T., and Brack, 
A. (2018) A hydrothermal-sedimentary context for the origin of life. Astrobiology 18:259-293.

White, L.M., Shibuya, T., Vance, S.D., Christensen, L.E., Bhartia, R., Kidd, R., Hoffmann, A., Stucky, G.D., Kanik, I., and Russell, M.J. (2020) Simulating serpentinization as it could apply to the emergence of life using the JPL hydrothermal reactor. Astrobiology 20:307-326.

Yamaguchi, A., Yamamoto, M., Takai, K., Ishii, T., Hashimoto, K., and Nakamura, R. (2014) Electrochemical $\mathrm{CO}_{2}$ reduction by Ni-containing iron sulfides: how is $\mathrm{CO}_{2}$ electrochemically reduced at bisulfide-bearing deep-sea hydrothermal precipitates?. Electrochim Acta 141:311-318.

Yang, D., Peng, S., Hartman, M.R., Gupton-Campolongo, T., Rice, E.J., Chang, A.K., Gu, Z., Lu, G.Q., and Luo, D. (2013) Enhanced transcription and translation in clay hydrogel and implications for early life evolution. Nat Sci Rep 3, doi: $10.1038 /$ srep03165.

Zhu, T.F., and Szostak, J.W. (2009) Coupled growth and division of model protocell membranes. J Am Chem Soc 131: 5705-5713.
Address correspondence to:

B. Rasmussen

School of Earth Sciences

The University of Western Australia

Perth, WA 6009

Australia

E-mail: Birger.Rasmussen@uwa.edu.au

Submitted 30 March 2020

Accepted 7 September 2020

Associate Editor: Nita Sahai

\section{Abbreviations Used}

$\mathrm{BIF}=$ banded iron formation

$\mathrm{nt}=$ nucleotides

$\mathrm{TEM}=$ transmission electron microscope 